DOI: $10.31548 /$ machenergy.2020.02.151-156

УДК 621.867 .133

\title{
CRITERIA FOR EVALUATION OF EFFICIENCY OF USING MACHINES IN AGRICULTURAL COMPLEX
}

\author{
L. L. Titova
}

National University of Life and Environmental Sciences of Ukraine, Ukraine.

Speciality of article: 133 - industry engineering.

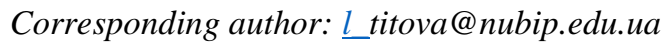

Article history: Received - January 2020, Accepted-April 2020.

Bibl. 19, fig. 2, tabl. 1.

Abstract. Comprehensive assessment of the use of grain harvesters is the result of simultaneous and coordinated research of a set of private qualitative and quantitative indicators that reflect the main aspects of operation of grain harvesters in given economic conditions, and generalized conclusions on the results of comparing actual values of private indicators with basic in previous periods in different conditions, desirable, etc.). The need for a comprehensive assessment of the use of grain harvesters arose based on the requirements of comparing the results of a single grain harvester or several machines combined into a harvesting unit or harvesting complex, not only on individual indicators, but also on a generalized criterion.

The main task of research into the efficiency of technical systems, including grain harvesters, is to choose a strategy for using machines that provides the best results in these conditions. To date, when choosing a strategy for a given operation, the criteria of minimum cost, minimum labor costs or maximum useful effect, such as productivity, are most often used.

Analysis of scientific research of many domestic and foreign scientists has shown that the easiest to determine, but reliable are the indicators that take into account the functioning of the machine over time. Such indicators include, first of all, the most common and fairly universal technical and economic indicator of machine performance, as well as the utilization rate of change time, indicators of machine reliability, etc. These indicators are applicable to assess the use of the entire fleet of grain harvesters. Widely used indicators have not only advantages in their use, but also disadvantages.

Key words: criterion, grain harvesting machine, harvesting and transport complex, grain culture, efficiency.

\section{Introduction}

To date, widely used in feasibility studies of various technological processes, including harvesting cereals, techniques developed in the early 20th century [1], taking into account the minimum full cost of a given operation or use of the machine [2].

\section{Formulation of problem}

Thus [3], when using the criterion - the minimum cost [4], first calculate the direct operating costs for harvesting cereals according to formula (1), and then they are attributed to the harvested area or to the gross grain harvest [5]:

$$
\mathrm{C}=\mathrm{C}_{s}+\mathrm{C}_{d}+\mathrm{C}_{M R}+\mathrm{C}_{A M}+\mathrm{C}_{a w},
$$

where $\mathrm{C}_{s}$ - salaries of combine harvesters, UAH;

$\mathrm{C}_{d}$ - depreciation deductions for the renovation of a combine harvester, UAH;

$\mathrm{C}_{M R}$ - costs for repair, maintenance and storage of combines, UAH;

$\mathrm{C}_{A M}$ - cost of consumables (fuel, lubricants and auxiliary materials), UAH;

$\mathrm{C}_{a w}$ - cost of ancillary works (transportation and refueling, lubricants, etc.), UAH.

The choice of combine harvesters when updating the fleet of combine harvesters [6] is recommended to be carried out according to the following main criteria: the degree of reduction of the cost of work [7], reducing the need for fuel and mechanization [8].

Then methods were used based on determining the efficiency of capital investments [9], or its inverse value the payback period [10].

\section{Analysis of recent research results}

A number of works have been published, in which a comparison of technological processes in crop production taking into account energy consumption is given [11].

Thus, in the research [12] the minimum energy consumption is estimated taking into account the number of technical means involved in the technological process (TP) and their energy saturation (Nt power of the internal combustion engine) [13]:

$$
\sum\left(n_{m} \cdot N_{m}\right) \rightarrow \min .
$$

Scientists have formed a whole group of individual performance indicators, which were defined as the ratio of economic result (or effect) to one of the indicators of economic resource or their corresponding growth [14].

The indicators of economic resources include, in 
particular:

$>$ labor costs (estimated productivity) [15];

$>$ production assets (estimated rate of return) [16];

$>$ capital investments (the efficiency of capital investments is estimated taking into account the growth of production) [17].

The unit of profitability of production was also used as a unit indicator of efficiency [18].

All of the above indicators suggest a cost principle in assessing efficiency. These criteria are somewhat onesided, but in some cases they are quite acceptable [19].

\section{Purpose of research}

The purpose of these studies is to determine the criteria for assessing the effectiveness of the use of machines in the agro-industrial complex.

\section{Results of research}

Proposed and applied to the comparison of combine harvesters Don-1500B, Don-2600 and Western 8570 a comprehensive indicator in the form of a function of the quality of the combine, which represents the volume of the triangular pyramid in space

$$
V=\frac{1}{6} X Y Z
$$

where $\mathrm{X}, \mathrm{Y}, \mathrm{Z}$ - respectively, the loss, crushing and clogging of the grain, deposited in space in Cartesian rectangular coordinates.

In the study it is proposed to evaluate the agrotechnological efficiency of combine harvesters according to the generalized criterion, which is defined as the average value of combine throughput of all maximum values of this indicator obtained for possible combinations of grain harvesting conditions in this soil-climatic zone. However, this generalized criterion of efficiency can be used only with a significant amount of statistical information.

From the known researches at calculation of standard sizes of grain harvesters for different regions of Ukraine apply the generalized zonal coefficient $\mathrm{Kz}$ that considers humidity of straw, clutter and fallowness by a stalk and unevenness of a crop on length of a run. This article presents the values of short circuits for the regions of Ukraine, table 1.

Table 1. The value of the generalized zonal coefficient.

\begin{tabular}{|c|c|}
\hline Regions of Ukraine & $K z$ \\
\hline Kyiv & 0.82 \\
\hline Cherkasy & 0.71 \\
\hline Vinnitsa & 0.92 \\
\hline Poltava & 0.82 \\
\hline Zhitomir & 0.78 \\
\hline Mikolayiv & 0.67 \\
\hline
\end{tabular}

However, the coefficient $\mathrm{Kz}$ takes into account the indicators of the state of the crop being harvested and does not take into account one of the most important indicators of the work of combine harvesters in the economy, the intensity of their use. The article proposes a universal (in the opinion of the authors of the article) indicator of combine operation, which is defined as the ratio of the share of gross grain threshing by a combine or a group of combines in total threshing by all combines to the share of one combine or group of combines in the combine fleet. This indicator is called the lead factor by the authors of the work. The advance coefficient was determined for 13 groups of combines that differ in seasonal grain threshing. This factor is used to characterize combine harvesters. However, it is difficult to use it as an indicator of assessing the conditions of use of combine harvesters.

Very often, to compare the use of combine harvesters, a target function is used that takes into account the minimum loss or crushing of grain.

Scientists have developed various methodological approaches to modeling the efficiency of combine harvesters. Thus, in the criterion of losses of efficiency $\mathrm{Kl}$ take into account the consumer properties of combine harvesters $\left(P_{1}, P_{2}, \ldots, P_{\mathrm{i}}\right)$; conditions of the agricultural producer $\left(Y_{1}, Y_{2}, \ldots, Y_{k}\right)$ and external conditions $\left(B_{1}, B_{2}, \ldots\right.$, $\left.B_{n}\right)$ :

$\mathrm{K}_{\mathrm{B}}=f\left(P_{1}, P_{2}, \ldots, P_{\mathrm{i}}, Y_{1}, Y_{2}, \ldots, Y_{k}, B_{1}, B_{2}, \ldots, B_{n}\right)$

However, quite often there are situations of uncertainty when choosing a criterion of effectiveness. In this case, it is necessary to apply additional principles or rules for selecting the criterion of effectiveness. The criterion of efficiency is made on the basis of one of the following concepts of rational selection of decisions: suitability, optimization, adaptation [].According to the concept of suitability, any solution will be rational if the value of the selected performance indicator is not below the required level $W^{n l}$, that is

$$
W(u) \geq W^{n l}, u \in U,
$$

where $U$ - many possible solutions.

According to the concept of optimization, a rational solution will be one that provides maximum effect

$$
W\left(u^{*}\right) \geq \max W(u), u \in U .
$$

According to the concept of adaptation, it is possible to quickly respond to current or projected information to achieve a given result under changing conditions of this operation.

According to the concept of adaptation, the result is considered the best $\mathrm{u}(\mathrm{t})$ of the many $\mathrm{U}(\mathrm{t}, \tau)$. The condition is fulfilled:

$$
W_{t}\left(u^{*}(t), \tau\right) \geq W_{t}^{n l} W(u(t), \tau), u(t) \in U(t, \tau)
$$

where $t$ - time, $\tau$ - ahead of the forecast.

Of the above concepts of rational choice of solutions to date, the most developed concept of suitability.

When choosing a method of harvesting cereals depending on the load on one unit during the season took into account 5 private indicators: the rate of harvesting cereals on the farm $(\mathrm{Rh})$, the probability of harvesting machine technological operation during the shift (P0), biological yield of cereals (By), losses ( $\mathrm{Lg}$ ) and injury of grain (Ig) by harvesting units.

For each selected private performance indicator, the ratio of its actual value was calculated $W_{\mu}$ to the necessary $W_{\mu}^{n l}$.

$$
K_{\mu}=W_{\mu} / W_{\mu}^{n l}
$$

For the ideal technology of harvesting grain crops all value $W_{\mu}=W_{\mu}^{n l}$ that is $K_{\mu}=1$. 
In this case, the ideal assembly technology is conventionally represented by a polygon with the number of angles equal to the number of private efficiency indicators. In this case, the angles of the polygon are placed on the axes of private indicators with coordinates equal to 1 (Fig. 1). The starting point $K_{\mu}$ of the minimizing indicators in the center of the intersection of the axes, and maximizing on the outer circle. After calculating the value of $K_{\mu}$ for real assembly technologies, polygons are constructed for the considered assembly technologies.

The technology of harvesting cereals was compared by a generalized factor:

$$
\mu_{0}=S_{\mathrm{C}} / S_{u} ; \mu_{0} \geq 1,
$$

where $S_{\mathrm{C}}, S_{u}$ - areas relating to comparable and ideal harvesting technologies.

The closer $\mu 0$ to 1 , the more efficient the harvesting technology.

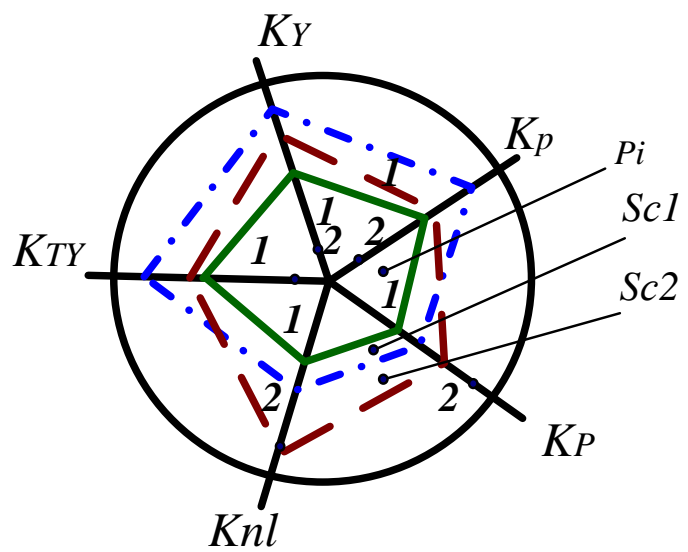

Fig. 1. Multicriteria evaluation model.

When comparing the efficiency of serial combine harvester and experimental, equipped with a device for prethreshing grain, the complex criterion took into account the biological yield of grain, which was collected and the proportion of crushed grain [].

When choosing the most efficient technology for harvesting sorghum sorghum, the maximum effect and minimum costs are formalized as follows:

$$
\left\{\begin{array}{c}
u^{*}: \max \varphi(K(u)) \\
u \in U \\
K_{1}(u) \geq 1 \\
K_{2}(u) \leq 1
\end{array}\right.
$$

where

$$
\begin{gathered}
K_{1}=\prod_{i=1}^{m_{1}} \frac{W_{i}}{W_{i}^{\mathrm{Hp}}} \\
K_{2}=\prod_{i=m_{1}+1}^{m} \frac{W_{i}}{W_{i}^{\mathrm{Hp}}}
\end{gathered}
$$

Dependence (10) is presented in the form of a graph (Fig. 2).

In fig. 2 characters $U_{1}, U_{2}, \ldots, U_{8}$ the cost-effect ratio for possible sorghum harvesting technologies is shown. The zone of effective sorghum harvesting technologies is zone A (see Fig. 2), and the best of the two technologies $U_{3}$ and $U_{4}$ is the technology $U_{3}$, as it meets the condition $K_{1}>1$, $K_{2}<1$, and the value of $K_{1}$ for $U_{3}$ is greater than for $U_{4}$, the value of $K_{2}$ for $U_{3}$ is less than for $U_{4}$.
The cost of transportation of hay rolls in a comprehensive criterion is appropriate if the difference between the components (one or more) operating costs that determine the cost of comparable technologies, more than $10 \%$.

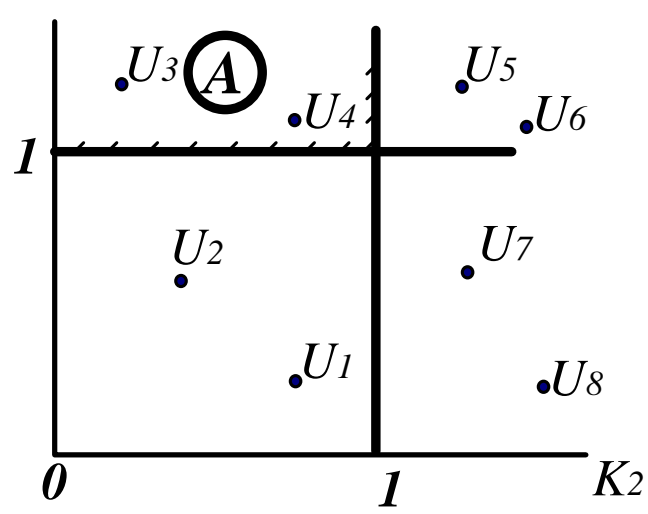

Fig. 2. Scheme of the method "cost - effect".

At a complex estimation of quality of work of grain harvesters used two unit indicators of loss of grain on the combine direct Lg and crushing Lcr.

We present a comprehensive criterion of efficiency in the form of:

$$
k_{E}=m\left\{\frac{P_{g}^{a l} P_{c r}^{a l}}{\gamma_{1} \gamma_{2} P_{g} P_{c r}}\right\}
$$

where $P_{g}^{a l}, P_{c r}^{a l}$ - respectively, the allowable levels of direct losses and grain crushing, $\gamma_{1}, \gamma_{2}$ - respectively, the coefficients of relative importance of direct losses and grain crushing.

\section{Conclusions}

1. Thus, when assessing the efficiency of agricultural machinery is currently the most commonly used concept of suitability, on the basis of which the criterion of efficiency is developed, taking into account the actual and desired level of private indicators that are part of it.

2. It is proposed to carry out a comprehensive assessment of the efficiency of grain harvesting machines according to the generalized criterion, taking into account the values of its private indicators and their relative importance.

\section{References}

1. Sergejeva N., Aboltins A., Strupule L., Aboltina B. (2018). Mathematical knowledge in elementary school and for future engineers. Proceedings of 17 th International Scientific Conference "Engineering for rural development". Jelgava, Latvia, May 23-25, 2018, Latvia University of Agriculture. Faculty of Engineering. Vol. 17, 1166-1172.

2. Dubbini M., Pezzuolo A., De Giglio M., Gattelli M., Curzio L., Covi D., Yezekyan T., Marinello F. (2017). Last generation instrument for agriculture multispectral data collection. CIGR Journal, vol. 19, 158163. 
3. Yata V.K., Tiwari B.C., Ahmad, I. (2018). Nanoscience in food and agriculture: research, industries and patents. Environmental Chemistry Letters, vol. 16, 7984.

4. Masek J., Novak P., Jasinskas A. (2017). Evaluation of combine harvester operation costs in different working conditions. Proceedings of 16th International Scientific Conference "Engineering for rural development". Jelgava, Latvia, May 24-26, Latvia University of Agriculture. Faculty of Engineering. Vol. 16, 1180-1185.

5. Rogovskii I., Grubrin O. (2018). Accuracy of converting videoendoscopy combine harvester using generalized mathematical model. Scientific Herald of National University of Life and Environmental Science of Ukraine. Series: technique and energy of APK. Kyiv, Ukraine. vol. 298, 149-156. doi: 10.31548/me.2018.04.149-156.

6. Viba J., Lavendelis E. (2006). Algorithm of synthesis of strongly non-linear mechanical systems. In Industrial Engineering - Innovation as Competitive Edge for SME, 22 April 2006. Tallinn, Estonia, 95-98.

7. Lио A.C.J., Gио Y. (2013). Vibro-impact Dynamics. Berlin: Springer-Verlag. 213.

8. Astashev V., Krupenin V. (2017). Efficiency of vibration machines. Proceedings of 16th International Scientific Conference "Engineering for rural development". Jelgava, Latvia, May 24-26, Latvia University of Agriculture. Faculty of Engineering. Vol. 16, 108-113.

9. Zagurskiy O., Ohiienko M., Rogach S., Pokusa T., Titova L., Rogovskii I. (2018). Global supply chain in context of new model of economic growth. Conceptual bases and trends for development of social-economic processes. Monograph. Opole. Poland, 64-74.

10. Drga R., Janacova D., Charvatova H. (2016). Simulation of the PIR detector active function. Proceedings of 20th International conference on Circuits, Systems, Communications and Computers (CSCC 2016), July 14-17, 2016, E D P Sciences, 17 Ave Du Hoggar Parc D Activites Coutaboeuf Bp 112, F-91944 Cedex A, France, vol. 76, UNSP 04036.

11. Novotny J. (2016). Technical and natural sciences teaching at engineering faculty of FPTM UJEP. Proceedings of 15th International Scientific Conference "Engineering for rural development". Jelgava, Latvia, May 23-25, Latvia University of Agriculture. Faculty of Engineering. Vol. 15, 16-20.

12. Pinzi S., Cubero-Atienza A.J., Dorado M.P. (2016). Vibro-acoustic analysis procedures for the evaluation of the sound insulation characteristics of agricultural machinery. Journal of Sound and Vibration, vol. 266 (3), 407-441.

13. Rogovskii I. L. (2019). Systemic approach to justification of standards of restoration of agricultural machinery. Machinery \& Energetics. Journal of Rural Production Research. Kyiv. Ukraine. Vol. 10, No 3, 181187.

14. Rogovskii I. L. (2019). Consistency ensure the recovery of agricultural machinery according to degree of resource's costs. Machinery \& Energetics. Journal of Rural Production Research. Kyiv. Ukraine. Vol. 10, No 4, 145150.
15. Lyudmila Titova, Ivan Rogovskii. (2014). The effectiveness of technical exploitation of the forest MES. MOTROL. Motorization and power industry in agriculture. Vol. 16, № 3. 313-321.

16. Lyudmila Titova, Ivan Rogovskii. (2015). Improving the recovery efficiency of machines for forestry work. MOTROL. Motorization and Energetics in Agriculture. Vol. 17, № 3. 298-310.

17. Lyudmila Titova, Ivan Rogovskii. (2017). System of control of parameters technical condition of machines for forestry work. TEKA. An International Quarterly Journal on Motorization, Vehicle Operation, Energy Efficiency and Mechanical Engineering. Lublin-Rzeszów. Vol. 17. No 3. 73-82.

18. Rogovskii Ivan, Titova Liudmyla, Novitskii Andriy, Rebenko Victor. (2019). Research of vibroacoustic diagnostics of fuel system of engines of combine harvesters. Proceedings of 18th International Scientific Conference "Engineering for rural development". Jelgava, Latvia, May 22-25, Latvia University of Agriculture. Faculty of Engineering. Vol. 18, 291-298.

19. Titova L. L., Rogovskii I. L. (2017). Technology recovery of power device of machines for forestry work. Scientific Herald of National University of Life and Environmental Science of Ukraine. Series: Technique and energy of APK. Kyiv. No 258. 369-380.

\section{Список літератури}

1. Sergejeva N., Aboltins A., Strupule L., Aboltina B. Mathematical knowledge in elementary school and for future engineers. Proceedings of 17th International Scientific Conference "Engineering for rural development". Jelgava, Latvia, May 23-25, 2018, Latvia University of Agriculture. Faculty of Engineering. Vol. 17, pp. 1166-1172.

2. Dubbini M., Pezzuolo A., De Giglio M., Gattelli M., Curzio L., Covi D., Yezekyan T., Marinello F. Last generation instrument for agriculture multispectral data collection. CIGR Journal, vol. 19, 2017, pp. 158-163.

3. Yata V.K., Tiwari B.C., Ahmad, I. Nanoscience in food and agriculture: research, industries and patents. Environmental Chemistry Letters, vol. 16, 2018, pp. 79-84.

4. Masek J., Novak P., Jasinskas A. Evaluation of combine harvester operation costs in different working conditions. Proceedings of 16 th International Scientific Conference "Engineering for rural development". Jelgava, Latvia, May 24-26, 2017, Latvia University of Agriculture. Faculty of Engineering. Vol. 16, pp. 1180-1185.

5. Rogovskii I., Grubrin O. Accuracy of converting videoendoscopy combine harvester using generalized mathematical model. Scientific Herald of National University of Life and Environmental Science of Ukraine. Series: technique and energy of APK. Kyiv, Ukraine. vol. 298, 2018, pp. 149-156. doi: 10.31548/me.2018.04.149-156.

6. Viba J., Lavendelis E. Algorithm of synthesis of strongly non-linear mechanical systems. In Industrial Engineering - Innovation as Competitive Edge for SME, 22 April 2006. Tallinn, Estonia, pp. 95-98.

7. Lио A.C.J., Gио Y. Vibro-impact Dynamics. Berlin: Springer-Verlag, 2013. 213 p. 
8. Astashev V., Krupenin V. Efficiency of vibration machines. Proceedings of 16th International Scientific Conference "Engineering for rural development". Jelgava, Latvia, May 24-26, 2017, Latvia University of Agriculture. Faculty of Engineering. Vol. 16, pp. 108-113.

9. Zagurskiy O., Ohiienko M., Rogach S., Pokusa T., Titova L., Rogovskii I. Global supply chain in context of new model of economic growth. Conceptual bases and trends for development of social-economic processes. Monograph. Opole. Poland, 2018, pp. 64-74.

10. Drga R., Janacova D., Charvatova H. Simulation of the PIR detector active function. Proceedings of 20th International conference on Circuits, Systems, Communications and Computers (CSCC 2016), July 1417, 2016, E D P Sciences, 17 Ave Du Hoggar Parc D Activites Coutaboeuf Bp 112, F-91944 Cedex A, France, vol. 76, UNSP 04036.

11. Novotny $J$. Technical and natural sciences teaching at engineering faculty of FPTM UJEP. Proceedings of 15th International Scientific Conference "Engineering for rural development". Jelgava, Latvia, May 23-25, 2016, Latvia University of Agriculture. Faculty of Engineering. Vol. 15, pp. 16-20.

12. Pinzi S., Cubero-Atienza A.J., Dorado M.P. Vibro-acoustic analysis procedures for the evaluation of the sound insulation characteristics of agricultural machinery. Journal of Sound and Vibration, vol. 266 (3), 2016, pp. 407-441.

13. Rogovskii I. L. Systemic approach to justification of standards of restoration of agricultural machinery. Machinery \& Energetics. Journal of Rural Production Research. Kyiv. Ukraine. 2019, Vol. 10, No 3, P. 181-187.

14. Rogovskii I. L. Consistency ensure the recovery of agricultural machinery according to degree of resource's costs. Machinery \& Energetics. Journal of Rural Production Research. Kyiv. Ukraine. 2019, Vol. 10, No 4, P. 145-150.

15. Lyudmila Titova, Ivan Rogovskii. The effectiveness of technical exploitation of the forest MES. MOTROL. Motorization and power industry in agriculture. 2014. Vol. 16, № 3. P. 313-321.

16. Lyudmila Titova, Ivan Rogovskii. Improving the recovery efficiency of machines for forestry work. MOTROL. Motorization and Energetics in Agriculture. 2015. Vol. 17, № 3. P. 298-310.

17. Lyudmila Titova, Ivan Rogovskii. System of control of parameters technical condition of machines for forestry work. TEKA. An International Quarterly Journal on Motorization, Vehicle Operation, Energy Efficiency and Mechanical Engineering. Lublin-Rzeszów. 2017. Vol. 17. No 3. P. 73-82.

18. Rogovskii Ivan, Titova Liudmyla, Novitskii Andriy, Rebenko Victor. Research of vibroacoustic diagnostics of fuel system of engines of combine harvesters. Proceedings of 18th International Scientific Conference "Engineering for rural development". Jelgava, Latvia, May 22-25, 2019, Latvia University of Agriculture. Faculty of Engineering. Vol. 18, pp. 291-298. DOI: 10.22616/ERDev2019.18.N451. Scopus.

19. Titova L. L., Rogovskii I. L. Technology recovery of power device of machines for forestry work. Scientific Herald of National University of Life and Environmental
Science of Ukraine. Series: Technique and energy of APK. Kyiv. 2017. No 258. P. 369-380.

\section{КРИТЕРИИ ОЦЕНКИ ЭФФЕКТИВНОСТИ ИСПОЛЬЗОВАНИЯ МАШИН В АГРОПРОМЫШЛЕННОМ КОМПЛЕКСЕ Л. Л. Титова}

Аннотация. Комплексная оценка использования зерноуборочных машин является результатом одновременного и согласованного исследования совокупности частных качественных и количественных показателей, отражающих основные аспекты эксплуатации зерноуборочных машин в заданных хозяйственных условиях, и обобщенные выводы о результатах сравнения фактических значений частных показателей с базовыми (плановыми, нормативными, лучшими из полученных в предыдущие периоды в разных условиях, желанными и т.п.). Необходимость комплексной оценки использования зерноуборочных машин возникла исходя из требований сопоставления результатов работы отдельной зерноуборочной машины или нескольких машин, объединенных в уборочную звено или уборочно-транспортный комплекс, не только за отдельными частными показателями, но и по обобщенному критерию.

Основной задачей исследований эффективности технических систем, в том числе и зерноуборочных машин, заключается в выборе стратегии использования машин, которая обеспечивает лучший результат в данных условиях. К настоящему времени при выборе стратегии выполнения заданной операции чаще всего применяют критерии минимальной себестоимости, минимальных затрат труда или максимального полезного эффекта, например, производительности труда.

Ключевые слова: критерий, зерноуборочная машина, уборочно-транспортный комплекс, зерновая культура, эффективность.

\section{КРИТЕРІЇ ОЦНКИ ЕФЕКТИВНОСТІ ВИКОРИСТАННЯ МАШИН В АГРОПРОМИСЛОВОМУ КОМПЛЕКСІ Л. Л. Тітова}

Анотація. Комплексна оцінка використання зернозбиральних машин $є$ результатом одночасного i узгодженого дослідження сукупності приватних якісних i кількісних показників, що відображають основні аспекти експлуатації зернозбиральних машин в заданих господарських умовах, i узагальнені висновки про результати порівняння фактичних значень приватних показників з базовими (плановими, нормативними, найкращими з отриманих в попередні періоди в різних умовах, бажаними i т.п.). Необхідність комплексної оцінки використання зернозбиральних машин виникла виходячи з вимог зіставлення результатів роботи окремої зернозбиральної машини або декількох машин, об'єднаних в збиральну ланку або збиральнотранспортний комплекс, не тільки за окремими приватними показниками, а й за узагальненим 
критерієм.

Основним завданням досліджень ефективності технічних систем, в тому числі і зернозбиральних машин, полягає у виборі стратегії використання машин, яка забезпечує найкращий результат в даних умовах. До теперішнього часу при виборі стратегії виконання заданої операції найчастіше застосовують критерії мінімальної собівартості, мінімальних витрат праці або максимального корисного ефекту, наприклад, продуктивності праці.

Ключові слова: критерій, зернозбиральна машина, збирально-транспортний комплекс, зернова культура, ефективність.

Л. Л. Тітова ORCID 0000-0001-7313-1253. 